\title{
Acid-base status, haemolymph composition and tissue copper accumulation in the shore crab Carcinus maenas exposed to combined copper and salinity stress
}

\author{
Jason M. Weeks*, Frank B. Jensen, Michael H. Depledge \\ Aquatic Biology Group, Institute of Biology, Odense University, DK-5230 Odense M, Denmark
}

\begin{abstract}
The effects of copper exposure on the shore crab Carcinus maenas (L.) were investigated at constant and changing salinities. Crabs were acclimated to $20 \mathrm{ppt}$ artificial seawater (SW) for $7 \mathrm{~d}$ at $15^{\circ} \mathrm{C}$, and were subsequently assigned to 1 of 6 groups: (1) maintained in $20 \mathrm{ppt} \mathrm{SW}$ (2) transferred to $10 \mathrm{ppt} \mathrm{SW}$ (3) transferred to $30 \mathrm{ppt} \mathrm{SW;} \mathrm{(4)} \mathrm{exposed} \mathrm{to} \mathrm{copper}\left(0.75 \mathrm{mg} \mathrm{Cu} \mathrm{l}^{-1}\right)$ in $20 \mathrm{ppt}$ SW; (5) exposed to copper with concurrent salinity change to $10 \mathrm{ppt} \mathrm{SW}$; or (6) exposed to copper with concurrent salinity change to $30 \mathrm{ppt} \mathrm{SW}$. Salinity change was associated with altered total ionic concentration of the haemolymph but only small changes in acid-base status. Copper exposure induced metabolic acidosis, with a progressive decrease in haemolymph $\mathrm{pH}$ and $\mathrm{HCO}_{3}^{-}$, both at constant and changing salinities. Thus, the effects of copper on acid-base status overrode the effects of salinity change. The acidosis in copper-exposed crabs was parallelled by a rise in haemolymph $\mathrm{Ca}^{++} \mathrm{Crabs}$ in poor condition and close to death exhibited low haemolymph $\mathrm{pH}$ values, suggesting that haemolymph pH may be a useful biomarker of physiological status. With metal exposure, copper accumulated in the gills and midgut gland but not in muscle. The accumulation of copper in gill tissue was positively correlated with salinity. During copper exposure the haemolymph copper concentration decreased. Haemolymph total protein and haemocyanin remained constant in crabs which were not exposed to copper, whereas these parameters decreased in copper-exposed crabs.
\end{abstract}

\section{INTRODUCTION}

Environmental changes often disturb the acid-base balance in aquatic animals. Both salinity change and copper exposure affect acid-base balance in crustaceans. In the shore crab Carcinus maenas (L.), transfer from fullstrength seawater to dilute seawater induces metabolic alkalosis, while the reverse transfer induces an acidosis (Truchot 1981). Exposure to copper typically induces metabolic acidosis (Boitel \& Truchot 1989, 1990). Responses to copper exposure with concurrent salinity changes are unknown. In Danish coastal waters, however, shore crabs inhabit waters of fluctuating salinity. Therefore the effects of exposure to another environ-

\footnotetext{
- Present address: Institute of Terrestrial Ecology, Monks Wood, Abbots Ripton, Huntingdon, Cambridgeshire PE17 2LS, United Kingdom
}

mental stressor (e.g. copper) should be considered in the light of effects due to concurrent changes in salinity.

A decrease in salinity is often associated with an increased uptake rate of trace metals (especially zinc and cadmium) in marine crustaceans (Nugegoda \& Rainbow $1989 \mathrm{a}$, b). Thus metal toxicity is potentially enhanced at low salinities due to the increased bioavailability of free metal ions (Zirono \& Yamamoto 1972). Such metal species have been identified as the principal chemical form bioavailable to organisms (Depledge \& Rainbow 1990). Carcinus maenas, however, is a resilient euryhaline crustacean, and there is the possibility that physiological adaptation to dilute media may not only help this crab to minimise ionic and osmotic fluxes, but also impair the uptake of dissolved trace metals (Depledge 1990).

Carcinus maenas is one of the most studied crustacean species (at least in northern climes). With regard 
to the responses of C. maenas to pollutants, the effects of copper have been studied most intensively. Copper uptake occurs both from food and seawater (see Depledge \& Rainbow 1990). Copper that is not bound to metallothionein in tissues at the site of entry (i.e. the gill when the seawater route is involved or in the midgut gland when uptake is via the food route) or to other cellular constituents, enters the haemolymph where non-specific binding to haemolymph proteins occurs (principally haemocyanin). The copper is then distributed among the tissues with accumulation occurring in the order: gill > midgut gland > muscle > carapace (Depledge 1989). Depending on exposure concentration, copper has been shown to alter tissue respiration rates (Kerkut \& Munday 1962), disturb circulatory and ventilatory activity (Depledge 1984a), disrupt feeding behaviour and endogenous rhythms (Depledge 1984b), and impair osmoregulatory ability (Bjerregaard \& Vislie 1986). Recent studies by Hansen et al. $(1992 a, b)$ indicate that the biochemical mechanism underlying loss of osmoregulatory ability involved the inhibition of gill $\mathrm{Na}^{+}, \mathrm{K}^{+}$-ATPase activity by copper ions. Other important effects following copper exposure included marked depression of the activities of phosphofructokinase in midgut gland and citrate synthetase in posterior gills. Also, lactate levels in gills, haemolymph and midgut gland were raised, as was glucose concentration in the haemolymph, indicating altered utilisation of aerobic vs anaerobic metabolic pathways. Energy charge potential was unaffected (Hansen et al. 1992b). Such changes are associated with the development of pathological processes leading to death.

In the present study the effects of copper on Carcinus maenas at both constant and changing salinity has been examined. In particular, changes in haemolymph composition and acid-base balance were investigated.

\section{MATERIALS AND METHODS}

Experimental crabs. Adult male Carcinus maenas were caught in seine nets from the coastal waters around Fyn, Denmark. The salinity of the water in which the crabs were caught varied approximately between 17 and $20 \mathrm{ppt}$ (depending on prevailing wind and current). Crabs were held subsequently in running seawater (SW) (with a salinity of ca $20 \mathrm{ppt}$ ) at the Odense University Marine Station at Bøgebjerggaard prior to use in experiments. Intermoult crabs ( 40 to $50 \mathrm{~g}$ wet wt) were assigned to one of twenty-four $10 \mathrm{l}$ acid-washed aquaria (with 4 crabs per aquarium). Crabs were acclimated to $20 \mathrm{ppt}$ artificial seawater (hw marinemix + Bioelements, Germany; background copper concentra- tion $5 \mu \mathrm{g} \mathrm{Cu} ~^{-1}$ ) at $15^{\circ} \mathrm{C}$, under constant aeration and a $12 \mathrm{~h}$ light: $12 \mathrm{~h}$ dark regime for $7 \mathrm{~d}$ prior to experimentation. The water was changed daily. Crabs were not fed during the acclimation and experimental periods. Subsequently, they were assigned to 1 of 6 groups: (1) maintained in 20 ppt SW (2) transferred to $10 \mathrm{ppt} \mathrm{SW}$; (3) transferred to $30 \mathrm{ppt} \mathrm{SW}$; (4) exposed to copper $(0.75 \mathrm{mg}$ $\mathrm{Cu}^{-1}$ ) in $20 \mathrm{ppt} \mathrm{SW}$; (5) exposed to copper with a concurrent salinity change to $10 \mathrm{ppt} S W_{\text {; }}$ or (6) exposed to copper with concurrent salinity change to $30 \mathrm{ppt}$ $\mathrm{SW}$. Copper was added from a stock solution of $\mathrm{CuCl}_{2} \cdot 2 \mathrm{H}_{2} \mathrm{O}$ (analytical grade, Merck, Germany).

Haemolymph samples were taken from crabs on Day 0 (i.e. control crabs in $20 \mathrm{ppt} \mathrm{SW}$, the normal salinity for the population from the southern Kattegat used in these experiments) and thereafter on Days 1,2,4 and 7. Sampling involved quickly withdrawing ca $800 \mu \mathrm{l}$ of haemolymph from each crab using a hypodermic needle inserted through the arthrodial membrane at the base of the 4 th or 5 th walking leg. These samples were used for the determination of ionic haemolymph composition. A separate group of crabs were used for investigating acidbase effects. These were sampled $(200 \mu \mathrm{l})$ at Times 0 , $2 \mathrm{~h}, 1 \mathrm{~d}, 3 \mathrm{~d}$ and $7 \mathrm{~d}$. All crabs were individually marked and sampled repeatedly throughout the experiment.

At the end of the experiment, the crabs were sacrificed and samples of midgut gland, gill and muscle tissue were removed, weighed and freeze-dried prior to metal analysis.

Analytical procedures. Haemolymph $\mathrm{pH}$ was measured immediately after sampling using the capillary $\mathrm{pH}$ electrode of a Radiometer BMS 3 electrode assembly (Copenhagen, Denmark). Haemolymph total carbon dioxide content $\left(C_{\mathrm{CO}_{2}}\right)$ was determined by the method of Cameron (1971). Partial pressure of carbon dioxide $\mathrm{PCO}_{2}$ was calculated from:

$$
P_{\mathrm{CO}_{2}}=\frac{\mathrm{C}_{\mathrm{CO}_{2}}}{\alpha_{\mathrm{CO}_{2}}\left(10^{\left(\mathrm{pH}^{2}-\mathrm{pK}^{\prime}\right)}+1\right)}
$$

and $\left[\mathrm{HCO}_{3}^{-}\right]$from:

$$
\left[\mathrm{HCO}_{3}^{-}\right]=\mathrm{C}_{\mathrm{CO}_{2}}-\left(\alpha_{\mathrm{CO}_{2}} \cdot P_{\mathrm{CO}_{2}}\right)
$$

using $\alpha_{\mathrm{CO}_{2}}$ (the $\mathrm{CO}_{2}$ solubility) and $\mathrm{pK}^{\prime}$ values predicted by the formulae of Heisler (1989).

Haemolymph chloride concentrations were determined colourimetrically (Radiometer CMT 10). After acid digestion of $0.05 \mathrm{ml}$ haemolymph samples, sodium, potassium, magnesium, calcium and copper total contents were measured by flame atomic absorption spectrophotometry (Perkin-Elmer 2380). To eliminate interactions among the various ions during analysis, mixed standards with ion concentrations similar to those in crab haemolymph were used. $\mathrm{La}_{2} \mathrm{O}_{3}$ was added to prevent phosphate interactions. Concentrations of haemocyanin $\left([\mathrm{Hc}]\right.$ in mmol $\mathrm{O}_{2}$ binding sites 
$\left.1^{-1}\right)$ were determined from the absorption peak near $335 \mathrm{~nm}$ of $1: 9$ dilutions of haemolymph samples, using a millimolar extinction coefficient of 17.3. The remainder of each haemolymph sample was stored at $-18^{\circ} \mathrm{C}$ for later use. Protein concentrations were measured by the Lowry technique (Lowry et al. 1951).

Dried tissue samples were digested at $100^{\circ} \mathrm{C}$ with $65 \%$ nitric acid (analytical grade, Merck, Germany) and evaporated to dryness. The residue was then redissolved in $2 \mathrm{ml} 0.2 \% \mathrm{HNO}_{3}$. Digests (and/or dilutions thereof as appropriate) were analysed for total copper using atomic absorption spectrophotometry (flame atomisation, Perkin-Elmer 2380). All tissue metal concentrations are expressed in $\mu \mathrm{g} \mathrm{g}^{-1}$ dry wt.

Data are presented as means \pm standard error and the significance of differences between means $(p<0.05)$ was tested using 2-tailed Students $t$-tests or by analysis of variance (ANOVA), both a priori to test for differences amongst all means, and a posteriori for differences between selected groups according to Sokal \& Rohlf (1981).

\section{RESULTS}

\section{Acid-base disturbances}

Salinity changes alone were associated with only minor acid-base disturbances. When salinity was lowered from 20 to $10 \mathrm{ppt}$, haemolymph $\mathrm{pH}$ remained at ca 7.84 during the $7 \mathrm{~d}$ of exposure (Fig. 1). An increase in salinity from 20 to $30 \mathrm{ppt}$ caused a minor metabolic acidosis after $7 \mathrm{~d}$. Exposure to copper was associated with significantly larger acid-base disturbances, both at constant and changing salinities. Crabs exposed to copper at constant salinity (20 ppt) gradually developed a metabolic acidosis with haemolymph $\mathrm{pH}$ and $\left[\mathrm{HCO}_{3}{ }^{-}\right]$declining whilst carbon dioxide tension was almost unchanged (Fig. 1, middle panel). Copper-exposure together with simultaneous salinity changes from either 20 to $10 \mathrm{ppt}$ or from 20 to $30 \mathrm{ppt}$ also led to typical metabolic acidoses (Fig. 1 upper and lower panels). In crabs kept at $20 \mathrm{ppt}$ in the absence of copper, haemolymph $\mathrm{pH}$ was 7.84 . The degree of depression of haemolymph $\mathrm{pH}$ after $7 \mathrm{~d}$ of copper exposure was dependent on salinity. The most severe acidosis occurred in copper-exposed crabs at $10 \mathrm{ppt}$ with haemolymph $\mathrm{pH}$ falling to 7.58 . At a salinity of $20 \mathrm{ppt}$, haemolymph $\mathrm{pH}$ fell to 7.64 while at $30 \mathrm{ppt}$, $\mathrm{pH}$ was reduced to 7.70 .

\section{Effects on haemolymph ion composition}

A change in salinity in the absence of copper caused only limited changes in the major haemolymph ions, characterised by a minor increase in the total haemo-
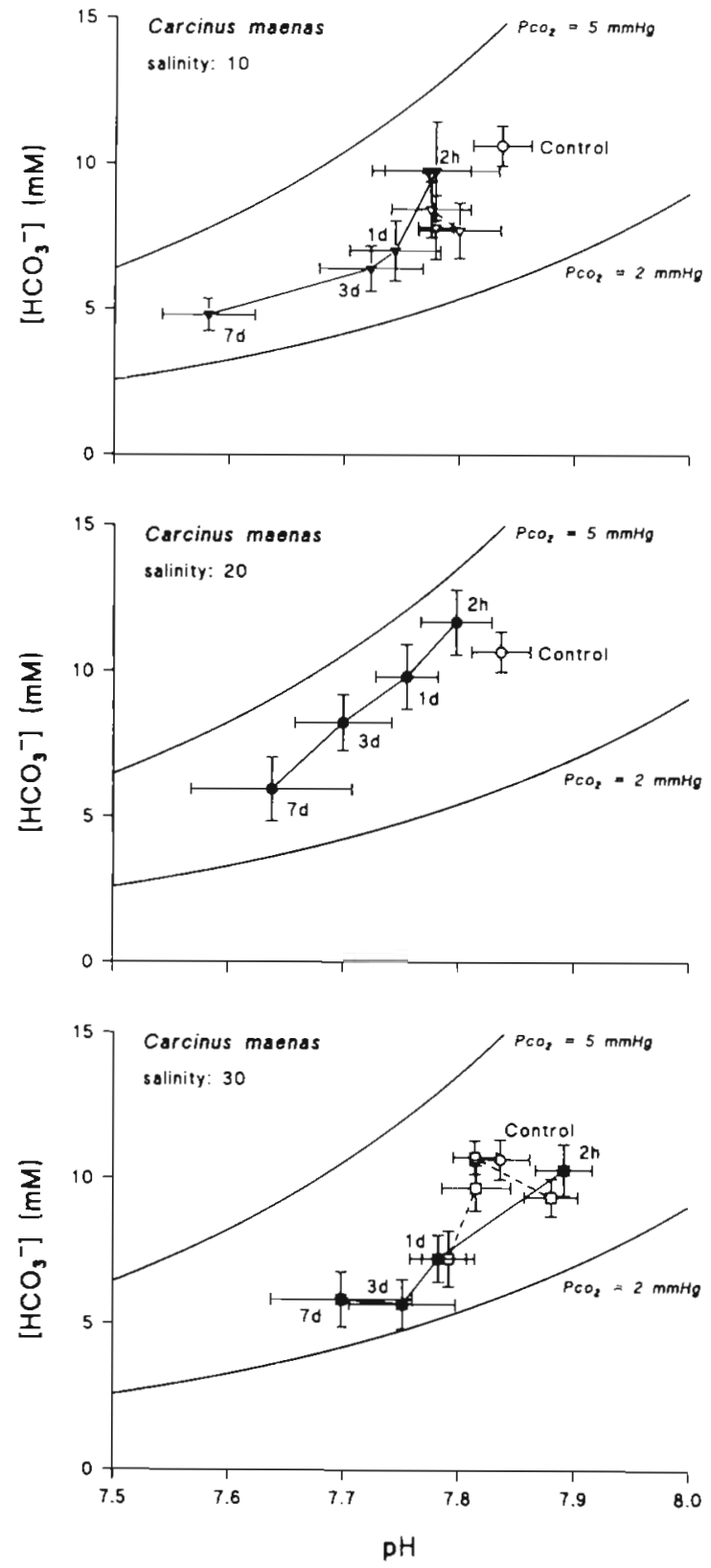

Fig. 1. Carcinus maenas. Haemolymph $\left[\mathrm{HCO}_{3}^{-}\right]$vs $\mathrm{pH}$ diagram with $\mathrm{PCO}_{2}$ isopleths depicting the changes in extracellular acid-base status (means \pm SEM) of shore crabs exposed to $0.75 \mathrm{mg} \mathrm{Cu} \mathrm{l}^{-1}$ at constant $(20 \mathrm{ppt}$ ) salinity (middle panel) or with a concurrent salinity change to $10 \mathrm{ppt}$ (upper panel) or $30 \mathrm{ppt}$ (lower panel). (0) Control acid-base status of crabs at salinity $20 \mathrm{ppt} ;(\boldsymbol{\nabla}, \bullet, \boldsymbol{\bullet})$ copper-exposed crabs; $(\nabla, 0)$ crabs exposed to salinity change alone. Numbers at points indicate time of copper exposure in hours (h) and days (d)

lymph ionic concentrations following an increase in salinity. Conversely, a small reduction in total haemolymph ions occurred after salinity was lowered. The data reflect the well-known ability of Carcinus maenas to regulate haemolymph osmolality at an almost con- 
stant level in the face of changing external osmolalities. Analysis of the data by ANOVA has shown that in the presence of copper, there was a significant decrease in haemolymph $\mathrm{Na}^{+}(21 \%, \mathrm{p}<0.01)$ and $\mathrm{Cl}^{-}(11 \%$, $p<0.05$ ) concentrations when the crabs were exposed to a salinity of 10 ppt (Fig, 2a, b). Similarly, concomitant exposure to copper and a salinity change to $30 \mathrm{ppt}$ resulted in a significant $(30 \%, p<0.01)$ increase in haemolymph $\mathrm{Cl}^{-}$to values above those measured in crabs not exposed to copper (Fig. 2b). Thus, copper appeared to impair the ability of C. maenas to osmoregulate.

A major effect of copper exposure was that it caused a significant rise in haemolymph calcium, irrespective of

the salinity regime to which the crabs had been subjected (Fig. 2C). In the absence of copper, haemolymph $\mathrm{Ca}^{++}$remained relatively constant. Haemolymph $\mathrm{Mg}^{++}$ion concentrations showed similar changes following both salinity transfer and copper-exposure. A significant $(p<0.01)$ increase in magnesium concentration was induced in crabs transferred to a salinity of $30 \mathrm{ppt}$ SW, whereas crabs transferred to salinities of 10 and 20 ppt exhibited a significant $(p<0.05)$ decrease in haemolymph magnesium (Fig. 2d).

ANOVA showed that haemolymph protein, haemocyanin and copper concentrations did not change in response to salinity transfer alone, whereas there was a significant $(\mathrm{p}<0.001)$ decrease in all these parameters in all copper-exposed crabs (Fig. 3).
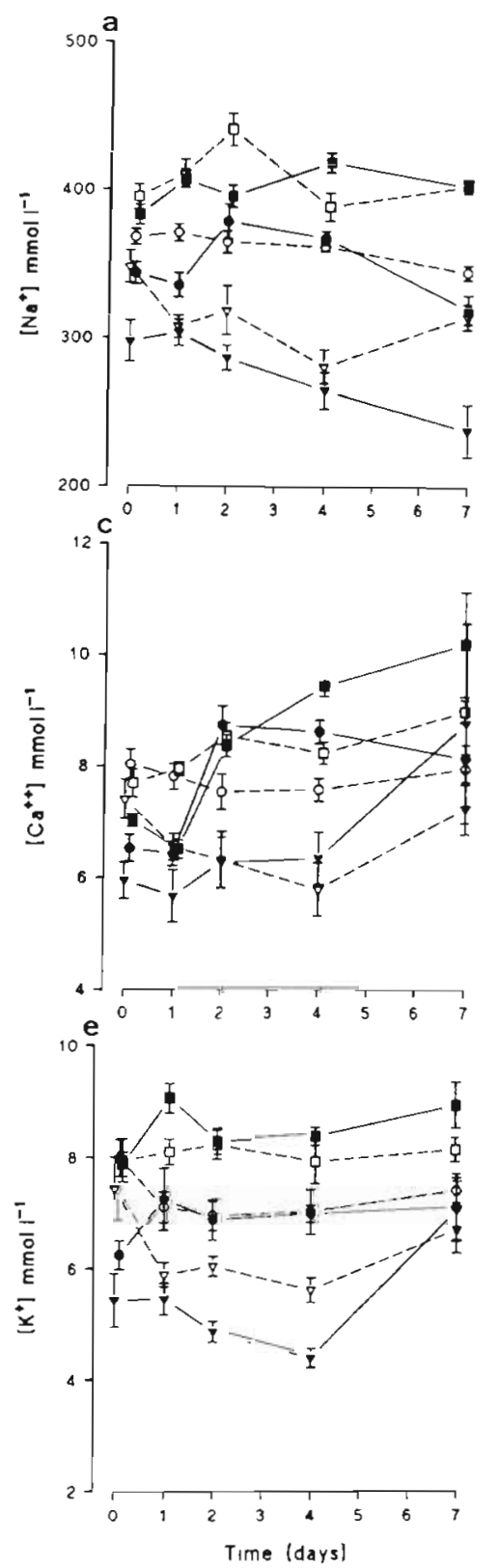
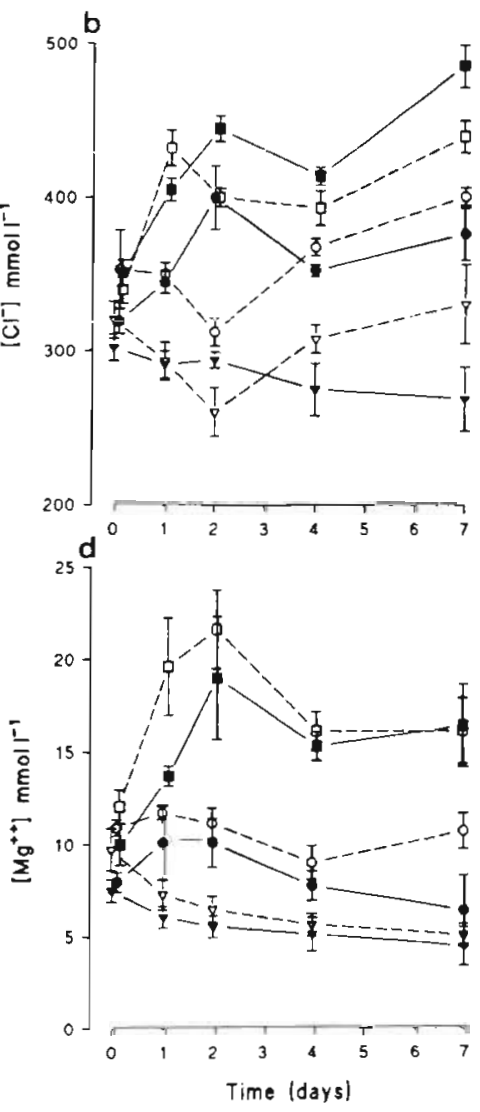

Fig. 2. Carcinus maenas. Timedependent changes in haemolymph ion concentration of crabs exposed to changing salinity (open symbols) and combined salinity and copper-exposure $\left(0.75 \mathrm{mg} \mathrm{Cu}^{-1}\right.$ ) (solid symbols). $(\nabla, \nabla)$ represents a salinity of $10 \mathrm{ppt} ;\left(0, \bullet 20 \mathrm{ppt}_{\mathrm{i}}(0, \bullet) 30 \mathrm{ppt}\right.$ seawater

\section{Tissue copper concentrations}

There were no significant changes in tissue water contents during the $7 \mathrm{~d}$ of cither salinity or copper exposure (i.e. no changes in the dry wt/wet wt ratio of the individual tissues were detected). Copper exposure brought about a several fold increase in gill tissue copper concentration, the degree of copper accumulation increasing with increasing salinity (Fig. 4). The copper concentration in the midgut gland of copper-exposed crabs increased significantly at salinities of 10 and 20 ppt but not at 30 ppt (Fig. 4) Copper exposure did not result in a significant increase in the copper concentrations in muscle tissues (Fig. 4).

\section{DISCUSSION}

Shore crabs acclimated to full strength seawater (33 ppt) and exposed to dissolved copper gradually developed a non-lactic haemolymph metabolic acidosis (Boitel \& Truchot 1989). The present study further elucidates this finding by demonstrating a metabolic acidosis in shore crabs from brackish water exposed to copper at both constant and changing (increasing or decreasing) salinity. This shows that the effects of copper on acidbase status override the effects of concurrent salinity changes.

Salinity changes per se caused only minor acid-base disturbances in crabs in 

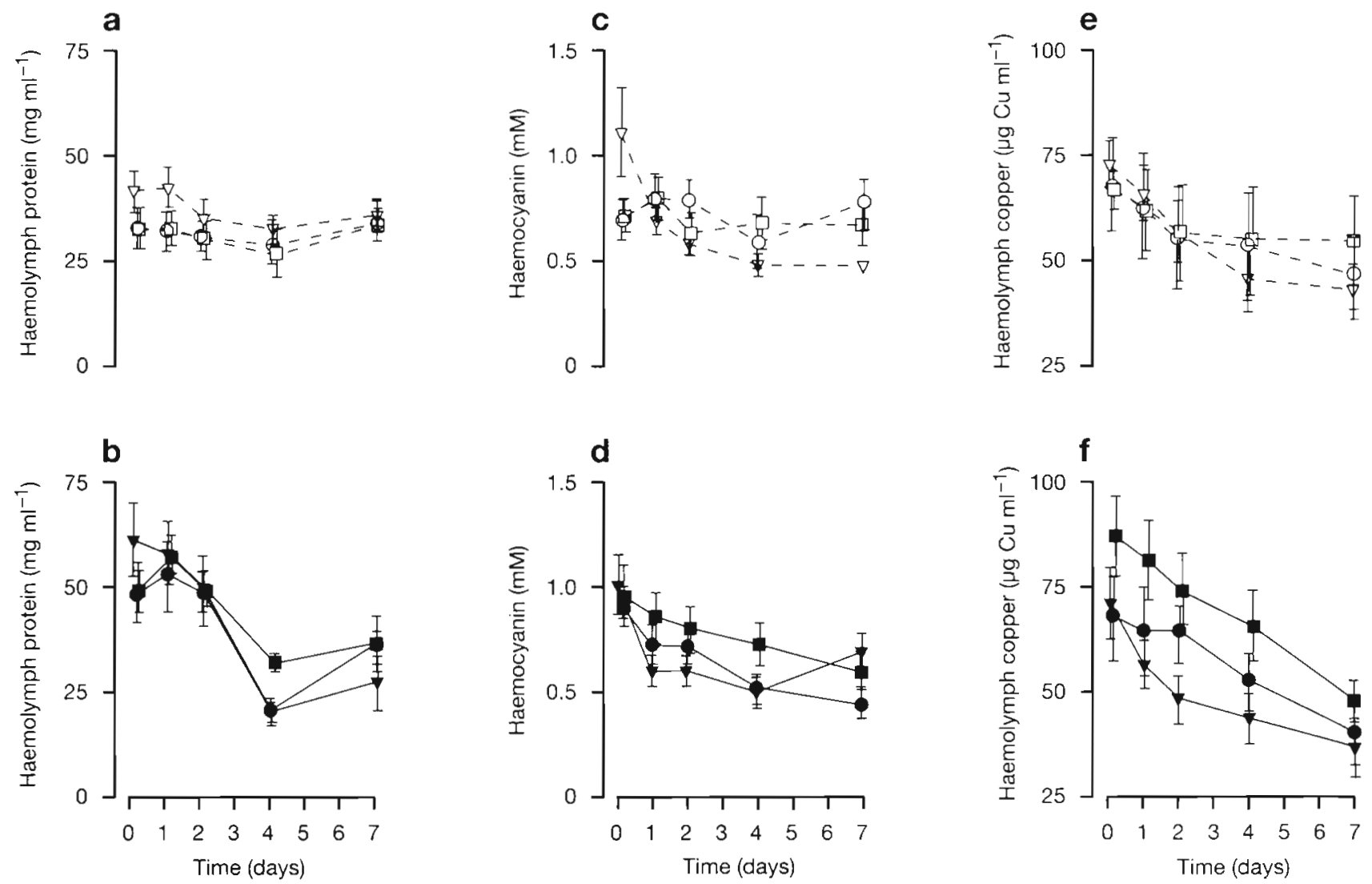

Fig. 3. Carcinus maenas. Time-dependent changes in ( $a, b)$ haemolymph protein, $(c, d)$ haemocyanin and (e, f) haemolymph copper of crabs exposed to changing salinity (open symbols) and combined salinity and copper exposure (0.75 mg Cu $\mathrm{l}^{-1}$ ) (closed symbols). $(\nabla, \nabla)$ represents a salinity of $10 \mathrm{ppt} ;(0, \bullet) 20 \mathrm{ppt}$; (, , 口) $30 \mathrm{ppt}$ seawater

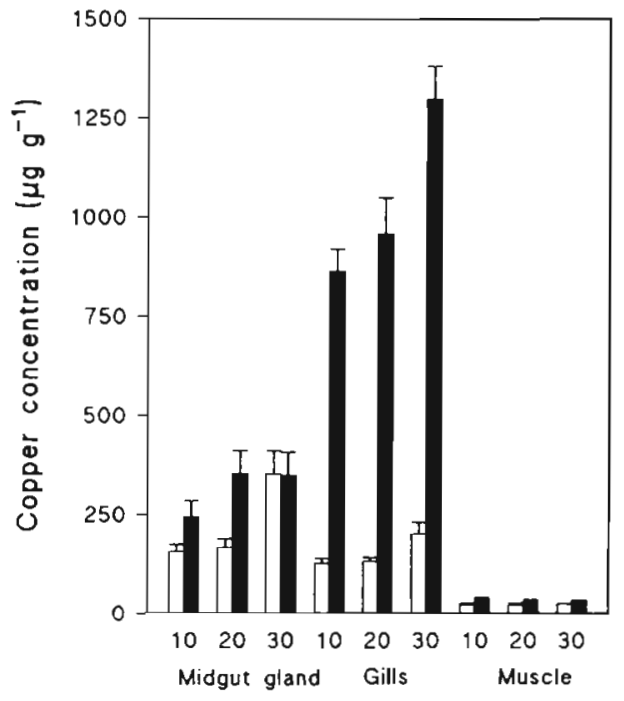

Fig. 4. Carcinus maenas. Mean ( \pm SEM) copper concentrations ( $\mu \mathrm{g} \mathrm{g}^{-1}$ dry $\mathrm{wt}$ ) in the midgut gland, gills and muscle tissues of crabs following $14 \mathrm{~d}$ exposure to either salinity change (unshaded bars) or combined salinity change with concomitant copper exposure $\left(0.75 \mathrm{mg} \mathrm{Cu} \mathrm{l}^{-1}\right)$ (shaded bars) the present study compared to those reported elsewhere (e.g. Truchot 1981, Boitel \& Truchot 1990). This may indicate that Danish crabs, which are exposed to very marked salinity variation in their natural habitat, regulate salinity-induced acid-base disturbances more rapidly and efficiently than Atlantic coast crabs (as used by Truchot 1981) that normally encounter relatively stable, higher salinities. Animals living under conditions of rapidly fluctuating salinity would clearly benefit from an ability to alter their surface permeability to minimize ionic and osmotic fluxes. Thus, Danish Carcinus maenas may be more readily able to alter their physiology to suit ambient conditions than crabs from more constant environments (Chan et al. 1992).

Although metabolic acidosis in copper-exposed crabs was quite marked, it was probably insufficient to result in death of the crabs. Crabs in poor condition, and close to death, invariably had low haemolymph $\mathrm{pH}$ values. Therefore, the likelihood of survival during the $24 \mathrm{~h}$ period after the final $\mathrm{pH}$ measurement could be predicted with a high degree of accuracy. Such a biomarker of condition might prove useful in future 
assessments of the physiological well-being of crabs exposed to a wide range of environmental perturbations (Depledge et al. 1992).

This present study showed relatively few and only minor changes in haemolymph ion concentrations upon exposure to salinity or copper stress (cf. Bjerregaard \& Vislie 1986). In full strength seawater, marine decapods are more or less iso-osmotic and iso-ionic with the ambient water, whereas in dilute seawater the haemolymph ionic concentrations is regulated at a hyperosmotic level by means of increased branchial ion uptake (Zanders 1980a). In the present study, crabs exposed to copper at a $10 \mathrm{ppt}$ salinity experienced a marked decrease in haemolymph sodium and chloride concentrations, which may be indicative of a net ion efflux at the branchial epithelium. This effect may be dependent on both copper concentration and season. Bjerregaard \& Vislie (1986) reported no effect upon haemolymph $\mathrm{Na}^{+}, \mathrm{K}^{+}$and $\mathrm{Cl}^{-}$concentrations following exposure to $0.25 \mathrm{mg} \mathrm{Cu} \mathrm{l}^{-1}$. $\mathrm{Na}^{+}$and $\mathrm{Cl}^{-}$concentrations decreased upon exposure to $0.5 \mathrm{mg} \mathrm{Cu} \mathrm{l}^{-1}$, the reduction being most significant during May and June. Copper-induced ion regulatory disturbances may be related to a direct inhibitory effect of copper on gill $\mathrm{Na}^{+}, \mathrm{K}^{+}$-ATPase in Carcinus maenas (Hansen et al. $1992 \mathrm{a}$, b), but might also be caused by increased passive ion fluxes due to increased branchial permeability.

At a salinity of 10 and 20 ppt the crabs in this study maintained their haemolymph magnesium concentrations at ca 8 to $11 \mathrm{mmol} \mathrm{l}^{-1}$ both in the presence and absence of copper (Fig. 2). At a salinity of $30 \mathrm{ppt}$, however, a marked increase in haemolymph magnesium concentration was induced. This finding contradicts the suggestion by Zanders (1980b) that Carcinus maenas maintains a low magnesium concentration by excretion via the antennal glands/bladder system (Zanders 1980b). It is possible that Danish crabs from low salinity environments take up magnesium to establish concentrations that are normal for Atlantic coast crabs (ca $18 \mathrm{mM}$; Chan 1990).

Haemolymph calcium concentrations increased in all copper-exposed crabs irrespective of salinity. This rise may reflect buffering of extracellular acidosis by means of dissolution of exoskeletal calcium carbonate (cf. Truchot 1987). Acidosis is, however, not always associated with a rise in haemolymph $\mathrm{Ca}^{++}$in crustaceans. Thus, the freshwater crayfish Astacus astacus developed the same degree of extracellular acidosis when exposed to acid water in the presence or absence of aluminium, but haemolymph calcium was only elevated in the aluminium-exposed specimens (Jensen $\&$ Malte 1990). This finding suggests that the presence and accumulation of metal in the gill tissue may somehow stimulate the carapace dissolution process. This could be via an inhibition of the branchial ion ex- change mechanisms that mediates transfer of acidbase equivalents between the animal and the environment and guarantees that normally (i.e. in the absence of metal) the external water rather than the carapace carbonate predominates as the proton sink (Cameron 1985).

Copper concentrations in the gills, muscle and midgut gland from control Carcinus maenas in the present study were consistent with the values reported by Bjerregaard \& Vislie (1986). The haemolymph present in the extracellular space in muscle may have led to an overestimation of muscle copper concentration in this study. Exposure to copper augmented concentrations of copper in the gill and midgut gland but not in the muscle. Earlier studies have indicated that the main target of metal action is the gill. Acute exposure to copper resulted in profound changes in gill ultrastructure and the production of excessive quantities of 'mucus' on the outer surface of the gills of the isopod Jaera nordmanni (Bubel 1976). Passive adsorption of copper onto the surfaces of the gill probably plays a role in copper uptake. Further, gill ion exchange components are probably affected by metal pollutants (Hansen et al. 1992a, b).

Total haemolymph protein concentrations in decapods are known to vary widely both inter- and intraspecifically (Depledge \& Bjerregaard 1989). The values measured in this study were in agreement with Bjerregaard \& Vislie (1986) (i.e. ca $57 \mathrm{mg} \mathrm{ml}^{-1}$ ). Boone \& Schoffeniels (1979) reported for C. maenas exposed to hypo-osmotic seawater (17 ppt) a doubling of haemocyanin concentration within $48 \mathrm{~h}$, increasing from $15-20$ to $35 \mathrm{mg} \mathrm{ml}^{-1}$. This was associated with an increase in haemolymph copper from 27 to $62 \mu \mathrm{g} \mathrm{ml}^{-1}$, but with no apparent increase in body copper. Calculations by Depledge \& Bjerregaard (1989) have cast considerable doubt on this finding, since mass balance determinations clearly demonstrate that the rise in haemocyanin copper concentration could not have been fulfilled without a major increase in whole body copper load. In the present study, salinity change alone did not affect haemolymph protein, haemocyanin or copper levels significantly. Weeks \& Rainbow (1992) also failed to show any increase in copper concentrations in the haemolymph of 2 species of talitrid amphipods following short-term hypo-osmotic stress. Combined salinity and copper stress, however, resulted in a lowering of all 3 crab haemolymph parameters. It is well known that many metabolic adjustments occur at the tissue level following changes of ambient salinity; these processes may well be transitory, however, the time course of re-adjustments (if any) is not known. These re-adjustments may be further complicated in the presence of dissolved copper. One interpretation of the observed decline in haemolymph copper in 
copper-exposed crabs may be that of 'overcompensation'. Copper taken up via the haemolymph at ambient concentrations is removed to the midgut gland, maintaining the copper level in the haemolymph and other internal organs relatively constant (Bryan 1976). At lowered salinities, and combined with an additional stress such as copper, then the rate of copper removal from the haemolymph to the midgut gland (with the involvement of metallothionein detoxification and a storage system) may be enhanced, to such an extent as to cause the observed lowering of haemolymph copper with a concomitant increase in midgut gland copper.

Acknowledgements. This work was carried out whilst J.M.W. was in tenure of a Royal Society European Fellowship. Hanne Ahm Pedersen and Annie Bach are thanked for their help with sample analyses. We gratefully acknowledge financial support from the Danish Natural Science Research Council.

\section{LITERATURE CITED}

Bjerregaard, P., Vislie, T. (1986). Effect of copper on ion- and osmoregulation in the shore crab Carcinus maenas. Mar Biol. 91: $69-76$

Boitel, F., Truchot, J.-P., (1989). Effects of sublethal and lethal copper levels on haemolymph acid-base balance and ion concentrations in the shore crab Carcinus maenas kept in undiluted seawater. Mar. Biol 103: 495-501

Boitel, F., Truchot, J.-P. (1990). Comparative study of the effects of copper on haemolymph ion concentrations and acid-base balance in shore crabs Carcinus maenas acclimated to full-strength or dilute seawater. Comp. Biochem. Physiol. 95C: $307-312$

Boone, W. R., Schoffeniels, E. (1979). Hemocyanin synthesis during hypo-osmotic stress in the shore crab Carcinus maenas (L.). Comp. Biochem. Physiol. 63B: 207-214

Bryan, G. W. (1976). Heavy metal pollution in the sea. In: Johnston, R. (ed.) Marine pollution. Academic Press, London, p. 185-302

Bubel, A. (1976). Histological and electron microscopical observations on the effects of different salinities and heavy metal ions, on the gills of Jaera nordmanni (Rathke) (Crustacea: Isopoda). Cell. Tissue Res. 167: 65-95

Cameron, J. N. (1971). Rapid method for determination of total carbon dioxide in small blood samples. J. appl. Physiol. 31: 632-634

Cameron, J. N. (1985). Compensation of hypercapnic acidosis in the aquatic blue crab, Callinectes sapidus: the predominance of external seawater over carapace carbonate as the proton sink. J. exp. Biol. 114: 197-206

Chan, H. M. (1990). Aspects of the biology of zinc in crabs with particular emphasis on the shore crab Carcinus maenas (L.). Ph.D. thesis, University of London

Chan, H. M., Bjerregaard, P., Rainbow, P. S., Depledge, M. H. (1992). Uptake of zinc and cadmium by two populations of shore crabs Carcinus maenas at different salinities. Mar. Ecol. Prog. Ser. 86: 91-97

Depledge, M. H. (1984a). Disruption of circulatory and respiratory activity in shore crabs (Carcinus maenas L.) exposed to heavy metal pollution. Comp. Biochem. Physiol. $78 \mathrm{C}: 445-459$
Depledge, M. H. (1984b). Disruption of endogenous rhythms in Carcinus maenas (L.) following exposure to mercury pollution. Comp. Biochem. Physiol. 78A: 375-379

Depledge, M. H. (1989). Re-evaluation of metabolic requirements for copper and zinc in decapod crustaceans. Mar. environ. Res. 27: 115-126

Depledge, M. H. (1990). Interactions between heavy metals and physiological processes in estuarine invertebrates. In: Chambers, P. L., Chambers, C. M. (eds.) Estuarine ecotoxicology. JAPAGA, Ashford, Ireland, p. 89-100

Depledge, M. H., Bjerregaard, P. (1989). Haemolymph protein composition and copper levels in decapod crustaceans. Helgoländer Meeresunters. 43: 207-223

Depledge, M. H., Amaral-Mendes, J. J., Daniel, B., Halbrook, R., Kloepper-Sams, P., Moore, M., Peakall, D. B. (1992). The conceptual basis of the biomarker approach. In: Peakall, D. B., Shugart, L. R. (eds.) Strategy for biomarker research and application in the assessment of environmental health. Lewis Publishers, Boca Raton (in press)

Depledge, M. H., Rainbow, P. S. (1990). Models of regulation and accumulation of trace metals in marine invertebrates. Comp. Biochem. Physiol. 97C: 1-7

Hansen, J. I., Mustatfa, T., Depledge, M. (1992a). Mechanisms of copper toxicity in the shore crab, Carcinus maenas I. Effects on Na,K-ATPase activity, haemolymph electrolyte concentrations and tissue water contents. Mar. Biol. 114: $253-257$

Hansen, J. I., Mustafa, T., Depledge, M. (1992b). Mechanisms of copper toxicity in the shore crab, Carcinus maenas II. Effects on key metabolic enzymes, metabolites and energy charge potential. Mar. Biol. 114: 259-264

Heisler, N. (1989). Parameters and methods in acid-base physiology. In: Bridges, C. R., Butler, P. J. (eds.) Techniques in comparative respiratory physiology: an environmental approach. Cambridge University Press, Cambridge, p. 305-332

Jensen, F. B., Malte, H. (1990). Acid-base and electrolyte regulation, and haemolymph gas transport in crayfish, Astacus astacus, exposed to soft, acid water with and without aluminium. J. comp. Physiol. (Sect. B) 160:483-490

Kerkut, G. A., Munday, K. A. (1962). The effect of copper on the tissue respiration of the crab, Carcinus maenas. Cah. Biol. mar. 3: $27-35$

Lowry, O. H., Rosebrough, N. J., Farr, A. L., Randall, R. J. (1951). Protein measurement with the folin phenol reagent. J. biol. Chem. 193: 265-275

Nugegoda, D., Rainbow, P. S. (1989a). Effects of salinity changes on zinc uptake and regulation by the decapod crustaceans Palaemon elegans and Palaemonetes varians. Mar. Ecol. Prog. Ser. 51: 57-75

Nugegoda, D., Rainbow, P. S. (1989b). Salinity, osmolality and zinc uptake in Palaemon elegans (Crustacea: Decapoda). Mar. Ecol. Prog. Ser. 55: 149-157

Sokal, R. R., Rohlf, F. J. (1981). Biometry. The principles and practice of statistics in biological research. W. H. Freeman \& Co., San Francisco, p. 776

Truchot, J.-P. (1981). The effect of water salinity and acidbase state on the blood acid-base balance in the euryhaline crab, Carcinus maenas (L.). Comp. Biochem. Physiol. 68A: 555-561

Truchot, J.-P. (1987). Comparative aspects of extracellular acid-base balance. Springer-Verlag, Berlin, p. 248

Weeks, J. M., Rainbow, P. S. (1992). The effect of salinity on copper and zinc concentrations in three species of talitrid amphipods (Crustacea). Comp. Biochem. Physiol. 101C: 399-405 
Zanders, I. P. (1980a). Regulation of blood ions in Carcinus maenas (L.). Comp. Biochem. Physiol. 65A: 97-108

Zanders, I. P. (1980b). The control of magnesium and sulphate excretion in Carcinus maenas (L.). Comp. Biochem.

This article was submitted to the editor
Physiol. 66A: 69-76

Zirino, A., Yamamoto, S. (1972). A pH-dependent model for the chemical speciation of copper, zinc, cadmium and lead in seawater. Limnol. Oceanogr. 17: 661-671

Manuscript first received: December 11, 1992

Revised version accepted: April 30,1993 